\title{
Analysis on the Significance of the Relationships Between Pay Satisfaction Dimensions and Organizational Citizenship Behavior
}

\section{Martin Serreqi}

Department of Management, Faculty of Economy,

University of Tirana

Abstract

The study looks into the relationships of the different dimensions of pay satisfaction with organizational citizenship behaviors (OCBs) directed towards both the individual and the organization. 500 white collar employees of different private sector companies participated in the study. With respect to the influence of the dimensions of pay satisfaction the results showed that there are significant relationships between pay level, pay raises and benefits with citizenship behavior directed at individuals. However, no such relationship exists between structure/administration and citizenship behavior directed at the organization. Limitations and future research directions conclude the study.

Keywords: Significance, Relationships Between Pay Satisfaction Dimensions, Organizational Citizenship Behavior

\section{Introduction}

Pay constitutes an essential aspect of doing business and a significant part of the success of any organization because it represents both, one of the largest organizational expenses, and one the most valued employee outcomes (Shaw et al., 1999). It rewards employees for their work and includes several forms of compensation such as "direct, cash payments (for example, salary); indirect, noncash payments (for example, benefits); the amount of pay raises and the process by which the compensation system is administered" (Williams et al., 2006, p. 392).

People work for many different reasons including assessment of one's self-worth and status (Blader \& Tyler, 2009), and purpose and intrinsic rewards (Lopes, 2011). However, for most of them pay is the only source of income and as such they depend on it to fulfill their existential needs (Dulebohn \& Werling, 2007). This makes pay the most important motivational factor (Locke, et. al, 1980), especially in relatively poorer countries with developing economies where many people struggle to fulfill these needs.

During the years, companies have surprisingly underestimated the importance of pay to their employees (SHRM, 2007), when it should have been their primary focus in order to best manage its significant impacts. First, as mentioned above pay is one of the largest organizational expenses and companies need to properly manage it in order to maximize the value of their investment. Second, because of its importance as a motivational factor, companies can use pay to enhance the contributions and the performance of their employees and to drive them closer to the organizational goals (Carraher, 2011; Singh \& Loncar, 2010). 
Third, companies use pay to recruit and retain the best employees (Galleta et al., 2011; Onn, 2012), which eventually ensures their success since companies are as good as their employees.

Organizations need to build the right pay structures in order to make sure that their employees are satisfied. The relationship between compensation and work outcomes is mediated by attitudinal reactions to pay (Dreher, Ash, and Bretz, 1988), such as pay satisfaction. A large body of research exits on pay satisfaction with most of it conducted on North American employees and, to a lesser degree on Western European ones. During recent years the focus of the research has shifted towards the outcomes of pay satisfaction (Vandenberghe and Tremblay, 2008).

The paper looks into the relationships of the different dimensions of pay satisfaction with organizational citizenship behaviors (OCBs) directed towards both the individual and the organization. Following the recent trends of the research on the subject, it uses a multidimensional instrument for measuring pay satisfaction, and it studies the relationship of pay satisfaction with an important outcome variable. More importantly the paper adds to the very small body of research on pay satisfaction in developing countries.

\section{Pay Satisfaction}

Pay satisfaction measures the gratifying sentiments of the employees towards their pay (Choudhury and Gupta, 2011; Miceli and Mulvey, 2000; Tekleab, Bartol, \& Liu, 2005). It has always been an important construct to both employees and organizations (Williams, McDaniel, \& Nhung, 2006; Singh \& Loncar, 2010), because of its critical mediating role between pay policies and relevant outcomes (Blau, 1994; Sturman \& Short, 2000).

The theoretical foundation of pay satisfaction is build upon the concepts of equity, discrepancy and administrative independence. Based on equity theory (Adams, 1963, 1965) the employee compares his pay situation with a referent other within the organization or outside of it and then reacts according to the difference. Discrepancy theory (Lawler, 1971, 1981) added important job characteristics to the comparison process and also valence, the importance one places on a certain outcome, to better explain the behaviors of the employees. The administrative independence concept (Heneman \& Schwab, 1979) further expanded the theoretical development by introducing the idea that pay satisfaction is not a global construct but rather a multidimensional one.

The advancements in understanding pay satisfaction have led to the changing of the methodological approach over time. Initially, pay satisfaction was considered a global construct and unidimensional measures were used to asses it. Researchers employed either ad-hoc measures, contextually tailored, or the pay satisfaction sub-scales of previously established job satisfaction measures (Fong \& Shaffer, 2003). During the following years, with the wide acceptance of the multidimensionality of pay satisfaction, several such measures were created (Heneman \& Schwab, 1985; Miceli \& Lane, 1991; Gerhart \& Milkovich, 1992; Williams et al., 2008).

The more recent trends in the field have focused on the consequences of pay satisfaction on work outcomes (Vandenberghe \& Tremblay, 2008). There is a growing body of research that explores the impact of pay satisfaction on different outcomes like individual (Khalid, 2020) and organizational (Currall et al., 2005) performance, organizational commitment (Meyer et 
al., 2002; Vandenberghe \& Tremblay, 2008), turnover intentions (Judge, Cable, \& Higgins, 2000; Williams et al., 2006).

\section{Organizational citizenship behaviors}

Organizational citizenship behaviors (OCBs) represent "individual behaviors that are discretionary, not directly or implicitly recognized by the formal reward system, and in the aggregate promote the efficient and effective functioning of the organization" (Organ, 1988, $p$ 4). It is critical for the survival of the organizations that employees are willing to occasionally engage in OCB (Barnard, 1938; Katz, 1964; Katz and Kahn, 1978; Robinson and Morrison, 1995). As an informal behavior that does not get rewarded (Organ \& Ryan, 1995), it exceeds any contractual agreement between the employee and the organization.

These behaviors can be categorized into two broad groups: those that focus on the organization (OCBOs) and those that focus on individual employees (OCBIs) that eventually benefit the organization (Williams \& Anderson, 1991). OCBOs include such behaviors as attending work more than the other employees, protecting organizational property and adhering to informal rules while OCBIs refers to such behaviors as going out of the way to help new employees, helping others who have been absent and assisting the supervisor when not asked.

The reason why employees engage in OCBs as extra-role behaviors is based on the premises of social exchange (Moorman, 1991), reciprocity (Organ, 1988,1990) and equity within the larger framework of psychological contracts (Rousseau, 1989). The employees will engage in beneficial behaviors for the organization when they (1) consider their employment relationship not just economical but also social and (2) when they reciprocate for the reasonable treatment from the company. As such, the expectations are that pay satisfaction and its dimensions will positively relate to OCBI and OCBO which is also supported by prior research (Blau, 1994; Faulk II, 2002; Lee, 1995; Welbourne \& Cable, 1995).

\section{Methods and Procedures}

It is generally accepted that Pay Satisfaction has four dimensions (Currall et al., 2005), namely pay level, benefits, pay raises and structure/administration. The first three dimensions refer to individual outcomes and the last one refers to organizational procedures and policies. As such, pay level, benefits and pay raises should relate with OCBI-s and structure/administration should relate with OCBO-s. Based on this argument I propose the following hypotheses:

Hypothesis 1a: Pay level will have a significant relationship with OCBI-s

Hypothesis $1 b$ : Benefits will have a significant relationship with OCBI-s

Hypothesis 1c: Pay Raises will have a significant relationship with OCBI-s

Hypothesis 1d: Structure/Administration will have a significant relationship with OCBO-s

500 questionnaires were collected electronically via Google forms from white collar employees of different private sector companies. Female respondents were $59.4 \%$ of the sample and the rest were males (40.6\%). Almost all of the employees sampled were under 45 years old ( $94.8 \%$ ), with those in the $35-45$ years age group comprising $52.2 \%$, followed by the 25-35 years group (23.4\%), and the rest being under 25 years group (19.2\%). More than half 
of the respondents $(51.8 \%)$ had less than 8 years of work experience and more than three quarters of the sample (76.6\%) had been less than 5 years at their current position. $57.8 \%$ of the employees did not have a managerial position, with the rest being managers of all three levels.

The data were collected using an Albanian version of the survey scales. The questionnaire had 42 questions, divided in three sections, and was developed by utilizing previously used and very reliable measures. The first section with 10 questions was used to acquire information on the participants' demographics characteristics. The second section with 18 questions asked the participants to rate their pay satisfaction levels. The final section with the remaining 14 questions asked the employees about their organizational citizenship behavior. The levels of pay satisfaction were rated with a five point Likert Scale with 1 being "Very Dissatisfied" and 5 being "Very Satisfied" and the levels of organizational citizenship behavior were rated with a five point Likert scale with 1 being "Never" and 5 being "Always".

Heneman and Schwab's (1985) four dimensional Pay Satisfaction Questionnaire, the most popular multifaceted measure of the construct, (Carraher and Buckley, 1996), (Vandenberghe and Tremblay, 2008) was used to measure pay satisfaction. The four dimensions measure satisfaction with pay level, benefits, pay raise and pay structure/ administration. There were four questions on pay level (e.g. How satisfied are you with your current salary? How satisfied are you with your take home pay?); four questions on benefits (e.g. How satisfied are you with the amount the company pays towards your benefits? How satisfied are you with the value of your benefits?); four questions on pay raise (e.g. How satisfied are you with the raises you have typically received in the past? How satisfied are you with how your raises are determined?); and six questions on pay structure/ administration (e.g. How satisfied are you with the way the organization administers pay? How satisfied are you with the organization's pay structure?). The Cronbach $\alpha$ estimates of internal consistency for Pay Level, Pay Raise, Benefits, and Pay Administration were $.899, .899, .828$, and .90 , respectively, well above the generally accepted lower limit of .70(Hair, et. al, 2010).

Organizational citizenship behavior was measured using Williams and Anderson's (1991) 14item organizational citizenship behavior (OCB) scale. This scale is designed to measure two different types of OCBs; seven items (1-7) measure behaviors that target a specific individual (OCBI), and the remaining seven items (8-14) measure those behaviors that focus on the organization (OCBO). Sample items include "Help others who have heavy workloads;" "Helps others who have been absent"(OCBI) and "Adhere to informal rules devised to maintain order;" "Conserve and protect organizational property"(OCBO). The Cronbach $\alpha$ estimates of internal consistency for organizational citizenship behavior were .72.

\section{Results}

To analyze our hypotheses about the significance of the relationships between the dimensions of pay satisfaction with OCBIs and OCBOs we use the Chi Square Independence Test. In order to establish a relationship between the variables at a $95 \%$ confidence interval we need to have a Asymptotic Significance (2-sided) of the Pearson Chi Square coefficient at less than p = 05 .

Table 1 shows the results of the test for pay level and OCBIs. The data shows that Asymptotic Significance (2-sided) has a value of $0.012<0.05$, which means that there is a significant relationship between pay level and OCBIs. 
Table 1 Test of the Pay Level and OCBIs relationship.

\begin{tabular}{|l|l|l|l|}
\hline Chi-Square Tests & & df & Asymptotic Significance \\
& Value & 8 &. -sided) \\
\hline Pearson Chi-Square & $19.681^{a}$ & 8 & .012 \\
\hline Likelihood Ratio & 18.940 & 1 & .015 \\
\hline Linear-by-Linear Association & 6.739 & & .009 \\
\hline N of Valid Cases & 500 & & \\
\hline
\end{tabular}

Table 2 refers to the test of the Benefits and OCBIs relationship. We expect a positive relationship between the two variables and the results support that. The value of $p=0.004$ which is much less than 0.05 and confirms that benefits have a significant relationship with OCBIs.

Table 2 Test of the Benefits and OCBIs relationship.

\begin{tabular}{|l|l|l|l|}
\hline Chi-Square Tests & & & $\begin{array}{l}\text { Asymptotic } \\
\text { Significance (2- } \\
\text { sided) }\end{array}$ \\
\hline & Value & df & 0.004 \\
\hline Pearson Chi-Square & $22.487^{a}$ & 8 & 0.006 \\
\hline Likelihood Ratio & 21.393 & 8 & 0.012 \\
\hline Linear-by-Linear Association & 6.310 & 1 & \\
\hline N of Valid Cases & 500 & & \\
\hline
\end{tabular}

The data of Table 3 shows the analysis of the Pay Raise and OCBIs relationship. We expect a positive relationship between the two variables and the results support that. The Asymptotic Significance (2-sided) of the Pearson coefficient is $0.004<0.05$ confirming the existence of a significant relationship between Pay Raises and OCBIs.

\section{Table 3 Test of the Pay Raises and OCBIs relationship}

\begin{tabular}{|c|c|c|c|}
\hline \multicolumn{4}{|l|}{ Chi-Square Tests } \\
\hline & Value & df & $\begin{array}{l}\text { Asymptotic } \\
\text { Significance (2- } \\
\text { sided) }\end{array}$ \\
\hline Pearson Chi-Square & $22.487^{a}$ & 8 & 0.004 \\
\hline Likelihood Ratio & 21.393 & 8 & 0.006 \\
\hline Linear-by-Linear Association & 6.310 & 1 & 0.012 \\
\hline $\mathrm{N}$ of Valid Cases & 500 & & \\
\hline
\end{tabular}

Looking at the results of the independence test, between Structure/Administration dimension and OCBOs, shown on table 4 we can see that the value of $\mathrm{p}=0.985$ which is greater than 0.05 . This result shows that the variables are statistically independent at a significant level and so it rejects the hypothesis that Structure/Administration variable will have a significant relationship with OCBOs. 
Table 4 Test of the Structure/Administration and OCBOs relationship

\begin{tabular}{|l|l|l|l|}
\hline Chi-Square Tests & & & $\begin{array}{l}\text { Asymptotic } \\
\text { Significance (2- } \\
\text { sided) }\end{array}$ \\
\hline & Value & df & 0.985 \\
\hline Pearson Chi-Square & $1.877^{\mathrm{a}}$ & 8 & 0.990 \\
\hline Likelihood Ratio & 1.653 & 8 & 0.666 \\
\hline Linear-by-Linear Association & 0.187 & 1 & \\
\hline N of Valid Cases & 500 & & \\
\hline
\end{tabular}

\section{Discussion and Conclusion}

The study discovered somewhat mixed results. Pay level, pay raises and benefits have significant relationships with citizenship behavior directed at individuals while structure/administration does not have a significant relationship with citizenship behavior directed at the organization. Such lack of a relationship between structure/administration and OCBO-s may be explained by the social-cultural environment where the study was conducted. In small countries, like Albania, social connections and relationships gain importance for the individuals. Because, citizenship behavior is not formally recognized by companies, employees will direct their behavior toward individuals and receive social rewards in the form of appreciation from their colleagues and eventually better social relationships with them.

The study adds to the very scarce literature on the links between pay satisfaction and organizational citizenship behaviors in developing economies. It is limited in that it discovers only the existence of significant relationships between these two factors without further exploring its nature. Future research should focus on the effects of overall pay satisfaction and its dimensions on citizenship behaviors in order to provide a complete insight to academics and practitioners alike.

\section{References}

[1] Adams, J. S. (1963). Toward an understanding of inequity. Journal of Abnormal and Social Psychology, 67, 422-436.

[2] Adams, J. S. (1965). Inequity in social exchange. Advances in experimental social psychology, 2, 267-299).

[3] Barnard, C. I. (1938). The Functions of the Executive. Cambridge, MA: Harvard University Press.

[4] Blader, S. L., \& Tyler, T. R. (2009). Testing and extending the group engagement model: Linkages between social identity, procedural justice, economic outcomes, and extra role behavior. Journal of Applied Psychology, 94, 445-464.

[5] Blau, G. (1994). Testing the effect of level and importance of pay referents on pay level satisfaction. Human Relations, 47, 1251-1268

[6] Carraher, S. M. (2011). Turnover prediction using attitudes towards benefits, pay, and pay satisfaction among employees and entrepreneurs in Estonia, Latvia, and Lithuania. Baltic Journal of Management, 6, 25-52.

[7] Carraher, S. M., \& Buckley, M. R. (1996). Cognitive complexity and the perceived dimensionality of pay satisfaction. Journal of Applied Psychology, 81, 102-109. 
[8] Choudhury, R. R., \& Gupta, V. (2011). Impact of Age on Pay Satisfaction and Job Satisfaction Leading to Turnover Intention: A Study of Young Working Professionals in India. Management and Labour Studies, 36(4), 354-358.

[9] Currall S.C., Towler A.J., Judge T.A., Kohn L. (2005). Pay satisfaction and organizational outcomes. Personnel Psychology 58, 613-640

[10] Dreher, G. F., Ash, R. A., \& Bretz, R. D. (1988). Benefit coverage and employee cost: Critical factors in explaining compensation satisfaction. Personnel Psychology, 41, 237-254

[11] Dulebohn, J. H., \& Werling, S. E. (2007). Compensation research past, present and future.

[12] Human Resource Management Review, 17(2), 191-207. http://dx.doi.org/10.1016/j.hrmr.2007.

[13] 03.002

[14] Faulk II, Larry Hugh, " Pay satisfaction consequences : development and test of a theoretical model" (2002). LSU Doctoral Dissertations. 321. https://digitalcommons.lsu.edu/gradschool_dissertations/321

[15] Fong, S. C. L., \& Shaffer, M. A. (2003). The dimensionality and determinants of pay satisfaction: A cross-cultural investigation of a group incentive plan. International Journal of Human Resource Management, 14, 559-580.

[16] Galletta, M., Portoghese, I., \& Battistelli, A. (2011). Intrinsic motivation, job autonomy, and turnover intention in the Italian healthcare: The mediating role of affective commitment. Journal of Management Research, 3(2), 1-19.

[17] Gerhart, B., \& Milkovich, G. T. (1992) Employee compensation: Research and practice. In Dunnette, M.D., \& Hough, L.M. (Eds.), Handbook of Industrial Organizational Psychology (2nd ed.) (Vol. 3, pp. 481-569). Palo Alto, CA: Consulting Psychologists Press

[18] Hair, J. F., Black, W. C., Babin, B. J., \& Anderson, R. E. (2010). Multivariate data analysis.

[19] Upper Saddle River: Prentice-Hall.

[20] Heneman, H. G. III, \& Schwab, D. P. (1979). Work and rewards theory. In D. Yoder \& H. G. Heneman, Jr. (Eds), ASPA handbook of personnel and industrial relations, 6(1)6(22). Washington, D.C.: Bureau of National Affairs.

[21] Heneman, H.G., \& D.P. Schwab. (1985). Pay Satisfaction: Its Multidimensional Nature and Measurement. International Journal of Psychology, 20, 129-141

[22] Judge, T., Cable, D., \& Higgins, C. (2000). The employment interview: A review of recent research and recommendations for future research. Human Resource Management Review, 10(4), 383-406.

[23] Katz, D. (1964). The motivational basis of organizational behavior. Behavioral Science, 9, 131-146.

[24] Katz, D., \& Kahn, R. L. (1978). The Social Psychology of Organizations. New York: John Wiley and Sons.

[25] Khalid, K. (2020). The Impact of Managerial Support on the Association Between Pay Satisfaction, Continuance and Affective Commitment, and Employee Task Performance. SAGE Open, 1-13.

[26] Lawler, E. E. III (1971). Pay and organizational effectiveness. New York: McGrawHill. 
[27] Lawler, E. E. III (1981). Pay and organizational development. Reading, MA: AddisonWesley.

[28] Lee, C. (1995). Prosocial Organizational Behaviors: The Roles of Workplace Justice, Achievement Striving, and Pay Satisfaction. Journal of Business and Psychology, 10, 197-206.

[29] Locke, E. A., Feren, D. B., McCaleb, V. M., Shaw, K. N., \& Denny, A. T. (1980). The relative effectiveness of four methods of motivating employee performance. In K. D. Duncan, M. M. Gruenberg, \& D. Wallis (Eds.), Changes in working life (pp. 363-388). New York, NY: Wiley.

[30] Lopes, H. (2011). Why do people work? Individual wants versus common goods. Journal of Economic Issues, 45(1), 57-74. http://dx.doi.org/10.2753/JEI00213624450104

[31] Meyer, John P, Stanley, David J, Herscovitch, Lynne, \& Topolnytsky, Laryssa. (2002). Affective, continuance, and normative commitment to the organization: A metaanalysis of antecedents, correlates, and consequences. Journal of vocational behavior, 61(1), 20-52.

[32] Miceli, M. P., \& Lane, M. C. (1991). Antecedents of pay satisfaction: A review and extension. In K. Rowland \& G.R. Ferris (Eds.), Research in Personnel and Human Resources Management (pp 235-309). Greenwich, CT: JAI Press.

[33] Miceli, M. P., \& Mulvey, P. W. (2000). Consequences of satisfaction with pay systems: Two field studies. Industrial Relations, 39(1), 62-86. http://dx.doi.org/10.1111/0019-8676.00153

[34] Moonnan, R. H. (1991). 'The relationship between organizational iustice and organizational citizenship behaviors: Do fairness perceptions influence employee citizenship? Journal of Applied Psychology, 76,845-855.

[35] Organ, D. W. (1988). Organizational citizenship behavior: The good soldier syndrome. Lexington, MA: Lexington Books

[36] Organ, D. W. (1990). 'The motivational basis of organizational citizenship behavior'. In: Staw, B. M. and Cummings, L. L. (Eds) Research in Organizational Behavior (Vol. 12, pp. 43-72). Greenwich, CT: JAI Press.

[37] Organ D. W., \& Ryan, K. (1995). A meta-analytic review of attitudinal and dispositional predictors of organizational citizenship behavior. Personnel Psychology, 48, 775-802.

[38] Robinson, S. L., \& Morrison, E. W. (1995). Psychological contracts and OCB: The effect of unfulfilled obligations on civic virtue behavior. Journal of Organizational Behavior, 16, 289-298.

[39] Rousseau, D. M. (1989). 'Psychological and implied contracts in organizations', Employee Responsibilities and Rights Journal, 8, 121-139.

[40] Shaw, J. D., Duffy, M. K., Jenkins G. D., \& Gupta, N. (1999). Positive and negative affect, signal sensitivity, and pay satisfaction. Journal of Management, 25, 189-206.

[41] Singh P., \& Loncar, N. (2010). Pay satisfaction, job satisfaction and turnover intent. Relations Industrielles/Industrial Relations, 65, 470-490.

[42] Society for Human Resource Management. (2007). 2007 Job Satisfaction Report. Alexandria, VA: Author.

[43] Sturman, M. C., \& Short, J. C. (2000). Lump-sum bonus satisfaction: Testing the

[44] construct validity of a new pay satisfaction dimension. Personnel Psychology, 53, 673-700. 
[45] Tekleab, A.G., Bartol, K.M., and Liu, W. (2005). Is It Pay Levels or Pay Raises That Matter to Fairness and Turnover? Journal of Organizational Behavior, 26(8), 899921.

[46] Vandenberghe C, Tremblay M. (2008). The Role of Pay Satisfaction and Organizational Commitment in Turnover Intentions: A Two-Sample Study . Springer Science+Business, 22, 275-286.

[47] Welbourne, T. M., \& Cable, D. M. (1995). Group incentives and pay satisfaction: Understanding the relationship through an identity theory perspective. Human Relations, 48, 711-726.

[48] Williams, L.J., Anderson, S.E. (1991). Job satisfaction and organizational commitment as predictors of organizational citizenship and in-role behaviors. Journal of Management, 17, 601-617.

[49] Williams, M. L, Brower, H. H, Ford, L. R, Williams, L. J, Carraher, S. M. (2008). A omprehensive model and measure of compensation satisfaction. Journal of Occupational and Organizational Psychology, 81, 639-668.

[50] Williams, M. L, McDaniel, M. A, Nguyen, T. N. (2006). A Meta-Analysis of the Antecedents and Consequences of Pay Level Satisfaction. Journal of Applied Psychology , 91(2), 392-413. 